\title{
Transforming growth factor- $\beta 1$ inhibits luteinization and promotes apoptosis in bovine granulosa cells
}

\author{
Xiaofeng Zheng, Derek Boerboom and Paul D Carrière \\ Faculté de Médecine Vétérinaire, Centre de Recherche en Reproduction Animale (CRRA), Université de Montréal, \\ St-Hyacinthe, Québec, Canada J2S 7C6 \\ Correspondence should be addressed to P D Carrière; Email: paul.d.carriere@umontreal.ca
}

\begin{abstract}
We have previously shown that TGFB1 inhibits estradiol $\left(E_{2}\right)$ and progesterone $\left(P_{4}\right)$ biosynthesis in FSH-stimulated bovine granulosa cells by selective inhibition of steroidogenic enzymes. The objective of this study was to assess the effects of TGFB1 on $E_{2}$ and $P_{4}$ steroidogenesis in bovine granulosa cells cultured in the absence of FSH and to measure the effects of TGFB1 on cell proliferation and apoptosis in the presence and absence of FSH. Bovine granulosa cells from 2 to $5 \mathbf{~ m m}$ follicles were cultured in serum-free medium for 2-6 days. In the absence of FSH, the secretion of $P_{4}$ increased with time in culture $(P<0.05)$. Addition of TGFB1 for 6 days decreased $P_{4}$ secretion and mRNA levels of the $P_{4}$ synthesis-associated genes STAR, CYP11A1, HSD3B1, and GSTA (P<0.05). In the absence of $F S H$, the secretion of $E_{2}$ decreased and addition of TGFB1 for 6 days partially reversed this decline and stimulated $E_{2}$ biosynthesis, CYP19A1 and HSD17B1 mRNA levels and CYP19A1 activity $(P<0.05)$. Conversely, TGFB1 did not affect $H S D 17 B 7$ expression and HSD17B-reducing activity. TGFB1 decreased the proportion of cells in the G0/G1 and S+ G2/M phases in FSHstimulated and unstimulated granulosa cells $(P<0.05)$. Furthermore, in the presence or absence of FSH, TGFB1 increased the proportion of cells in apoptosis measured by propidium iodide staining and flow cytometry and confirmed by increased levels of cleaved caspase-3 $(\boldsymbol{P}<\mathbf{0 . 0 5})$. Our results therefore indicate that TGFB1 inhibits luteinization in cultured bovine granulosa cells while maintaining an estrogenic phenotype, and this effect was associated with increased apoptosis.

Reproduction (2009) 137 969-977
\end{abstract}

\section{Introduction}

In the ovary, the destiny of the majority of developing follicles is atresia, and only a limited number of follicles will develop to the ovulatory stage. Apoptosis of granulosa cells is a hallmark of follicular atresia (Tilly et al. 1991). Many signaling processes are involved in the initiation of apoptosis, one of which is the proteolytic activation of caspase-3, which is a caspase common to several different apoptosis pathways (Matikainen et al. 2001, Johnson \& Bridgham 2002). Caspase-3 is actively involved in follicular atresia, and is present in the granulosa cells of atretic, but not healthy follicles (Boone \& Tsang 1998, Nicholas et al. 2005). Research on the mechanisms that regulate cell cycle progression have identified specific phases in which cells are more susceptible to apoptosis (Quirk et al. 2004). During the first gap phase or G1, cells are quiescent but potentially receptive to mitogenic stimuli, which stimulate cells to embark into the proliferative phases of the cell cycle consisting of the DNA synthesis phase (S), the second gap phase (G2), and the mitotic phase (M). In granulosa cells of the developing follicle, the G1/S transition phase is a critical checkpoint, as progression from the quiescent stage (G0/G1) to the $S$ phase requires the action of cell proliferation and survival factors such as insulin-like growth factor-1 (IGF1) and estradiol ( $E_{2}$; Hu et al. 2004, Quirk et al. 2004).

The secretion of $E_{2}$ and progesterone $\left(\mathrm{P}_{4}\right)$ and the autocrine or paracrine effects of these steroids are also important functions of granulosa cells during follicular development (Drummond 2006). Increased production of $E_{2}$ in granulosa cells requires transformation of androstenedione $\left(A_{4}\right)$ to estrone $\left(E_{1}\right)$ by cytochrome P450 aromatase (CYP19A1) activity and conversion of $E_{1}$ to $E_{2}$ by $17 \beta$-hydroxysteroid dehydrogenase (HSD17B)reducing enzyme activity (Mindnich et al. 2004, Zheng et al. 2008). In large antral and preovulatory follicles, granulosa cells develop the capacity to transform cholesterol into $\mathrm{P}_{4}$ through the expression of $\mathrm{P}_{4}$-synthetic enzymes, including cytochrome P450 side-chain cleavage (CYP11A1), 3 $\beta$-hydroxysteroid dehydrogenase (HSD3B1), and $\alpha$-glutathione S-transferase (GSTA; Bao \& Garverick 1998, Rabahi et al. 1999, Raffalli-Mathieu et al. 2007).

To understand ovarian follicle development, studies have focused on the regulation of granulosa cell steroidogenesis, proliferation, and apoptosis. In the last 
decade, many autocrine/paracrine growth factors, including transforming growth factor- $\beta 1$ (TGFB1), have been identified in the ovary and shown to regulate physiologic processes in granulosa cells. TGFB1 is expressed in the ovary of human, rodent, and sheep (Juengel \& McNatty 2005). In earlier studies, TGFB1 knockout mice did not survive past weaning age, which prevented researchers from defining the ovarian role of TGFB1 in vivo (Shull et al. 1992, Kulkarni et al. 1993). More recently, female TGFB1 knockout mice on the immunocompromized scid background have provided evidence that follicular estrogen synthesis is less sensitive to TGFB1 deficiency than luteal cell $\mathrm{P}_{4}$ synthesis, as TGFB1 null mutant mice had low serum $\mathrm{P}_{4}$ levels, but estrogen was unaffected (Ingman et al. 2006). In agreement with this in vivo result, TGFB1 stimulated $\mathrm{P}_{4}$ synthesis in cultured rodent granulosa cells (Dodson \& Schomberg 1987); however, TGFB1 also stimulated $E_{2}$ production (Adashi et al. 1989). Conversely, TGFB1 inhibited granulosa cell secretion of $E_{2}$ and $P_{4}$ from pigs and ruminants (Chang et al. 1996, Wandji et al. 1996, Ford \& Howard 1997, Juengel et al. 2004, Ouellette et al. 2005, Zheng et al. 2008). In the bovine species, TGFB1 expression was observed in granulosa cells of small but not of large antral follicles (Nilsson et al. 2003). In agreement with this finding, a previous study showed a negative relationship between follicular fluid TGFB1 and $E_{2}$ concentrations and between TGFB1 levels and follicle size (Ouellette et al. 2005). Concerning cell proliferation, TGFB1 inhibited EGF- or FSH-stimulated DNA synthesis and mitosis in cultured bovine, porcine, or ovine granulosa cells (Skinner et al. 1987, Gangrade \& May 1990, Juengel et al. 2004), but it increased FSH-stimulated DNA synthesis and mitosis in rat granulosa cells (Dorrington et al. 1993). The conflicting results of TGFB1 function in ovarian physiology among animal species further emphasize the multifunctional roles of TGFB1, which have been reported in many other tissues (Herrmann et al. 2002). The effects of TGFB1 also appear to be dependent on the stage of differentiation and the state of stimulation of the tissues examined in vitro.

In bovine granulosa cells, it is well established that TGFB1 negatively affects secretion of $\mathrm{E}_{2}$ and $\mathrm{P}_{4}$ (Wandji et al. 1996, Ouellette et al. 2005, Zheng et al. 2008). Our previous study showed that TGFB1 inhibits $E_{2}$ and $P_{4}$ syntheses without totally shutting down steroidogenesis in FSH-stimulated granulosa cells. However, the effects of TGFB1 on steroidogenesis in granulosa cells cultured in basal conditions without FSH and its effects on cell proliferation and apoptosis in $\mathrm{FSH}$-stimulated and -unstimulated granulosa cells remain unknown. Therefore, the objective of this study was to assess the effects of TGFB1 on steroidogenesis, cell proliferation, and apoptosis in cultured bovine granulosa cells.

\section{Results}

In granulosa cells cultured without $\mathrm{FSH}$ treatment, $\mathrm{E}_{2}$ accumulation in culture medium decreased from day 2 to day 6 (Fig. 1A). $P_{4}$ secretion increased from day 2 to day 6 (Fig. 1B). In agreement with increased secretion of $\mathrm{P}_{4}$ with time in culture, mRNA expression of the $\mathrm{P}_{4^{-}}$ related enzymes STAR, CYP11A1, HSD3B1, and GSTA also increased with time (Fig. 1D-G). A representative agarose gel from two replicates showing PCR products for each steroidogenic enzyme and housekeeping gene 1 b15 is shown in Fig. 1C.

The addition of TGFB1 during the 6-day culture period caused a significant $(P<0.05)$ dose-dependent inhibition of $\mathrm{P}_{4}$, and increased $\mathrm{E}_{2}$ secretion (Fig. $2 \mathrm{~A}$ and $\mathrm{B}$ ).
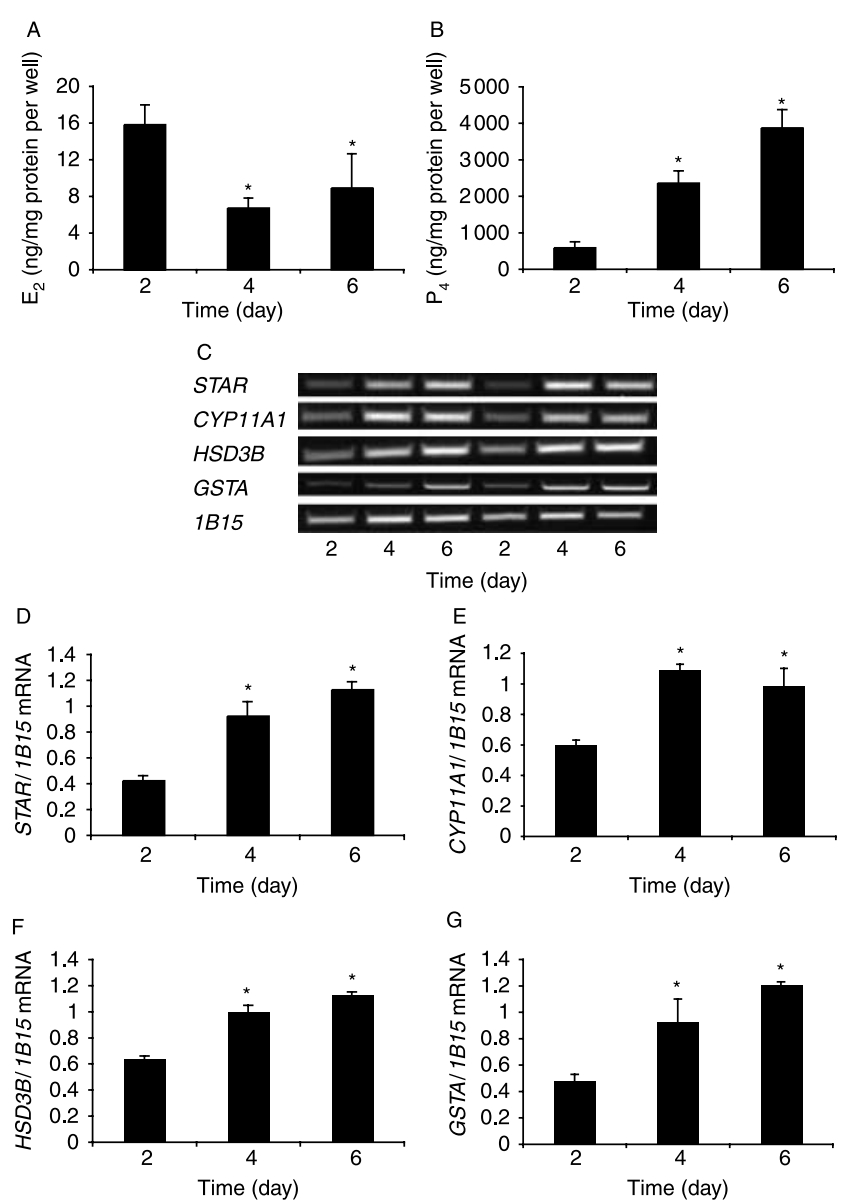
G

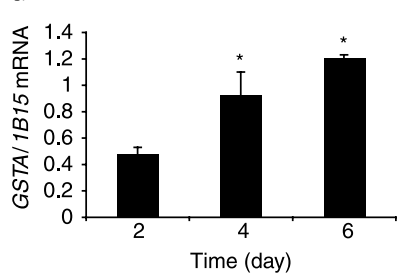

Figure 1 Effect of time in culture $\left(2,4,6\right.$ days) on secretion of $E_{2}$ and $P_{4}$ with $\mathrm{P}_{4}$ synthesis-associated gene expression in bovine granulosa cells cultured in serum-free medium in the absence of FSH. (A and B) The data represent the secretion of $\mathrm{E}_{2}$ and $\mathrm{P}_{4}$ during the previous $48 \mathrm{~h}$ of culture. (D-G) Transcript abundance of $\mathrm{P}_{4}$ synthesis-associated genes STAR, CYP11A1, HSD3B1, and GSTA mRNA was measured by semi-quantitative RT-PCR and normalized to the housekeeping gene 1b15. Data are means \pm S.E.M. of three separate culture replicates. Asterisk $(*)$ indicates that the mean is significantly different from control at day $2(P<0.05$, one-way ANOVA, with Dunnett's test). (C) A representative agarose gel from two replicates showing PCR products for each steroidogenic enzyme and housekeeping gene $1 \mathrm{~b} 15$. 

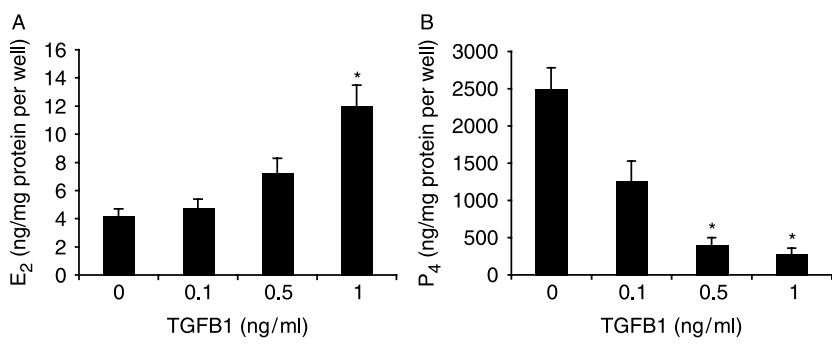

Figure 2 Effects of TGFB1 on (A) $E_{2}$ and (B) $P_{4}$ secretion in bovine granulosa cells cultured in the absence of FSH. Cells were cultured for 6 days without serum and treated with TGFB1 beginning at day 0 . The medium was collected on day 6 and the data represent steroids produced during the final $48 \mathrm{~h}$ of culture. Data were corrected for total cell protein and represent means \pm S.E.M. derived from four different pools of ovaries. The asterisk $\left(^{*}\right)$ indicates that steroid hormone secretion was significantly different from the 0 dose control group $(P<0.05, n=4$, one-way ANOVA, with Dunnett's test).

To determine whether the increase in $E_{2}$ secretion was due to an increase in CYP19A1 activity and HSD17Breducing activity, conversion of the tritiated steroid hormone precursors of $A_{4}, T$, and $E_{1}$ to $E_{2}$ was measured. When granulosa cells were cultured with $1 \mathrm{ng} / \mathrm{ml}$ of TGFB1, there was a significant increase $(P<0.05)$ of combined CYP19A1 activity and HSD17B-reducing activity relative to untreated cells, as measured by the conversion of $\left[{ }^{3} \mathrm{H}\right]-\mathrm{A}_{4}$ to $\left[{ }^{3} \mathrm{H}\right]-\mathrm{E}_{2}$ (Fig. 3A). The intermediate product $\left[{ }^{3} \mathrm{H}\right]-\mathrm{E}_{1}$ was not detected. TGFB1 at a dose of $1 \mathrm{ng} / \mathrm{ml}$ caused a significant increase $(P<0.05)$ in CYP19A1 activity, as measured by the conversion of $\left[{ }^{3} \mathrm{H}\right]-\mathrm{T}$ to $\left[{ }^{3} \mathrm{H}\right]-\mathrm{E}_{2}$ (Fig. 3B). TGFB1 did not alter HSD17B-reducing activity, as measured by the conversion of $\left[{ }^{3} \mathrm{H}\right]-\mathrm{E}_{1}$ to $\left[{ }^{3} \mathrm{H}\right]-\mathrm{E}_{2}$ (Fig. 3C). TGFB1 increased CYP19A1 and HSD17B1 mRNA levels $(P<0.05)$, but did not affect $H S D 17 B 7$ mRNA levels (Fig. 4A, C and D). Corresponding to the decreased secretion of $\mathrm{P}_{4}$, TGFB1 caused a significant inhibition $(P<0.05)$ in mRNA expressions of STAR, CYP11A1, HSD3B1, and GSTA (Fig. 4E-H).

At day 0 , the majority of granulosa cells were at G0/G1 phase (Fig. 5C and D). The percentage of cells in G0/G1 phase decreased with time in culture in the presence or absence of $\mathrm{FSH}$, and TGFB1 caused a significant decrease in the percentage of cells in G0/G1 with or without FSH (Fig. 5C and D, $P<0.05$ ). At day 0 , the proportion of cells in the proliferative phase of the cell cycle $(\mathrm{S}+\mathrm{G} 2 / \mathrm{M})$ was low $(\sim 10 \%)$. The proportion of $\mathrm{S}+\mathrm{G} 2 / \mathrm{M}$ cells did not change significantly with time in culture in FSH-stimulated cells, but TGFB1 treatment decreased the amount of proliferating cells at $144 \mathrm{~h}$. In the absence of $\mathrm{FSH}$, the proportion of $\mathrm{S}+\mathrm{G} 2 / \mathrm{M}$ cells decreased with time in culture and TGFB1 caused a marked decrease in the proportion of proliferating cells at $144 \mathrm{~h}$ (Fig. $5 \mathrm{E}$ and $\mathrm{F}, P<0.05$ ). The percentage of apoptotic granulosa cells (defined as $<2 n$ ) increased with time in culture in the presence or absence of $\mathrm{FSH}$.
(Fig. 5A and $\mathrm{B}, P<0.05)$. In FSH-stimulated granulosa cells, apoptosis increased by twofold compared with more than threefold increase in cells cultured without FSH. At 48, 96, and $144 \mathrm{~h}, \mathrm{TGFB} 1$ significantly increased the percentage of apoptotic cells in the presence or absence of $\mathrm{FSH}$, resulting in a proportion of more than $60 \%$ of apoptotic cells at $144 \mathrm{~h}$ (Fig. $5 \mathrm{~A}$ and $B, P<0.05)$. The effect of TGFB1 on the proportion of cells in apoptosis measured by propidium iodide (PI) staining and flow cytometry was also confirmed by increased levels of cleaved caspase-3 $(P<0.05$; Fig. 6A and $B$ ). In order to confirm the effects of TGFB1 on $E_{2}$ and $\mathrm{P}_{4}$ concentration in $\mathrm{FSH}$-stimulated and -unstimulated
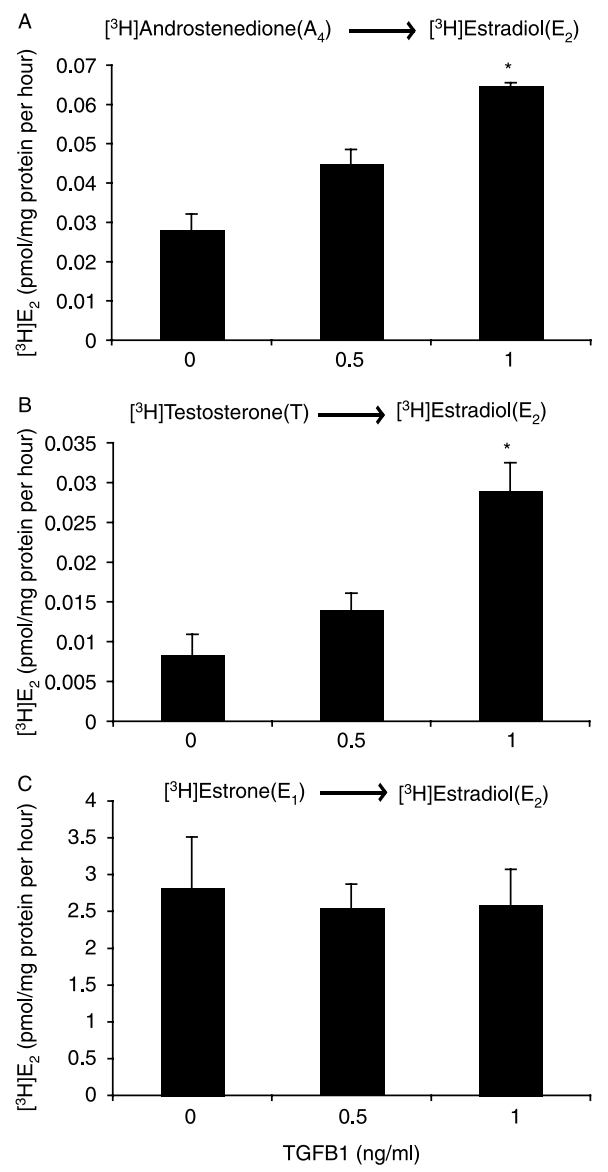

Figure 3 Effect of TGFB1 on conversion of androgens to $E_{2}$ and HSD17B-reducing activity in bovine granulosa cells cultured in the absence of FSH. Cells were cultured for 6 days in serum-free medium with TGFB1 treatment beginning on day 0 . The culture medium was replaced on day 6 with fresh medium containing labeled steroid precursor, and enzymatic activity assays were conducted as described in Materials and Methods. $\left[{ }^{3} \mathrm{H}\right] \mathrm{A}_{4}$ and $\left[{ }^{3} \mathrm{H}\right] \mathrm{T}$ were incubated for $48 \mathrm{~h}$ and $\left[^{3} \mathrm{H}\right] \mathrm{E}_{1}$ precursor was incubated with $10^{-6} \mathrm{M}$ (1000-fold excess) unlabeled $E_{1}$ for 1.5 h. Data are means \pm S.E.M. of three separate culture replicates. (A) Conversion of $\left[{ }^{3} \mathrm{H}\right] \mathrm{A}_{4}$ to $\left[{ }^{3} \mathrm{H}\right] \mathrm{E}_{2}$ (CYP19A1+ HSD17B-reducing activity) is shown. (B) Conversion of $\left[{ }^{3} \mathrm{H}\right] \mathrm{T}$ to $\left[{ }^{3} \mathrm{H}\right] \mathrm{E}_{2}$ (CYP19A1 activity) is shown. (C) Conversion of $\left[{ }^{3} \mathrm{H}\right] \mathrm{E}_{1}$ to $\left[{ }^{3} \mathrm{H}\right] \mathrm{E}_{2}$ (HSD17B-reducing activity) is shown. The asterisk $(*)$ indicates that enzyme activity is significantly different from the 0 dose control group $(P<0.05, n=3$, one-way ANOVA, with Dunnett's test). 

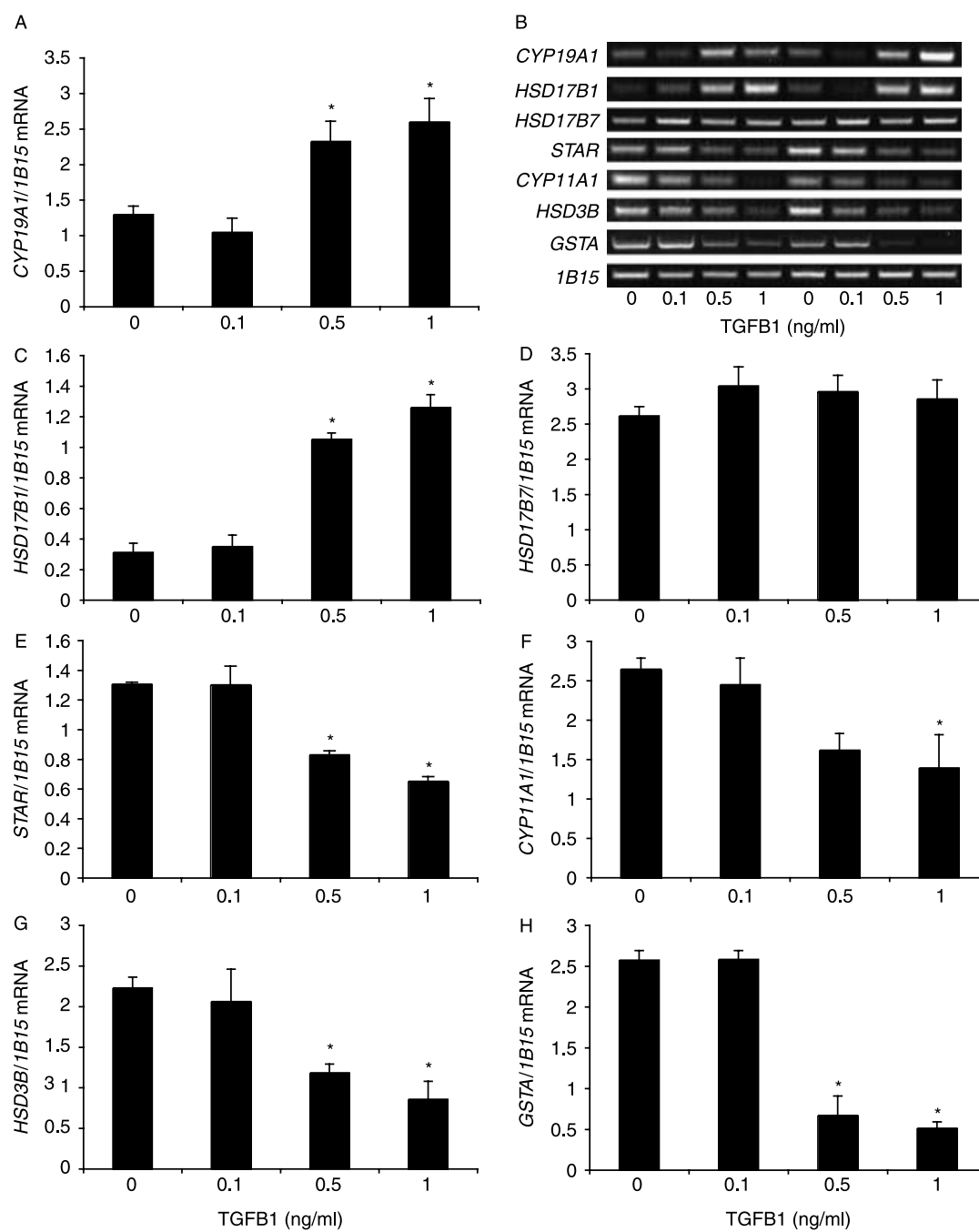
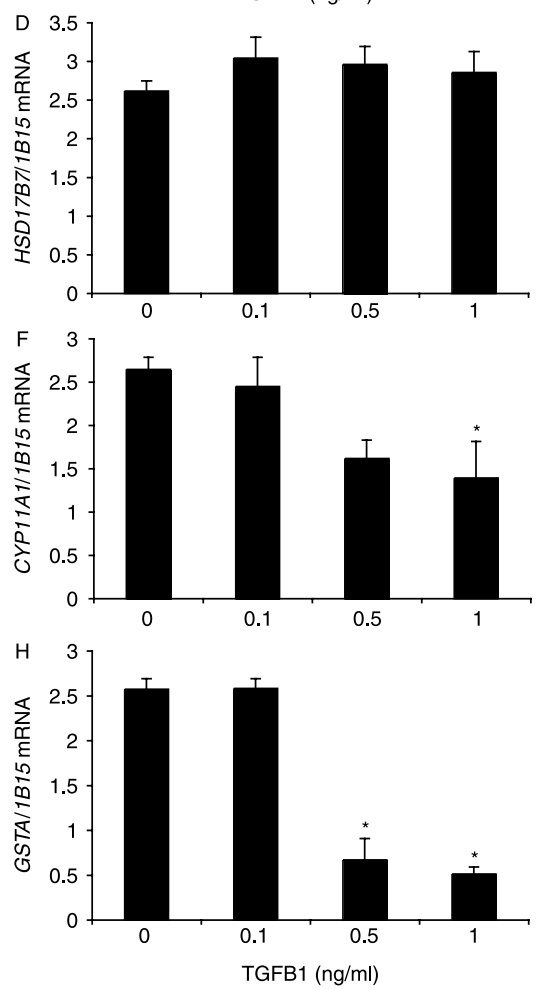

Figure 4 Effect of TGFB1 on mRNA expression of steroidogenic enzymes in bovine granulosa cells cultured in the absence of FSH. Cells were cultured in serum-free medium for 6 days in the presence of the stated doses of TGFB1 beginning on day 0. (A and $\mathrm{C}-\mathrm{H}$ ) Abundance of CYP19A1, HSD17B1, HSD17B7, STAR, CYP11A1, HSD3B1, and GSTA mRNA was measured by semi-quantitative RT-PCR and normalized to the housekeeping gene 1 b15. Data are means \pm S.E.M. of four separate culture replicates. Asterisk $\left(^{*}\right)$ indicates that mRNA content is significantly different from 0 dose control $(P<0.05$, one-way ANOVA, with Dunnett's test). (B) Representative agarose gels from two replicates showing PCR products for each steroidogenic enzyme and the housekeeping gene $1 b 15$ are shown. granulosa cells, the concentration of these steroid hormones was measured at day 6 in the culture media of cells used for Figs 5 and 6. In FSH-stimulated granulosa cells, TGFB1 inhibited $\mathrm{E}_{2}$ secretion $(35.9 \pm 5$ in control versus $2.6 \pm 1.6 \mathrm{ng} / \mathrm{mg}$ protein, $P<0.05$, $n=3)$ and $\mathrm{P}_{4}$ secretion $(1151 \pm 86$ in control versus $125 \pm 13 \mathrm{ng} / \mathrm{mg}$ protein, $P<0.05, n=3)$. In the absence of FSH, TGFB1 stimulated $E_{2}$ secretion $(3.5 \pm 0.2$ in control versus $5.7 \pm 0.1 \mathrm{ng} / \mathrm{mg}$ protein, $P<0.05, n=3$ ) and inhibited $\mathrm{P}_{4}$ secretion $(1005 \pm 153$ in control versus $108 \pm 14 \mathrm{ng} / \mathrm{mg}$ protein, $P<0.05, n=3)$.

\section{Discussion}

In vitro, granulosa cells harvested from follicles always spontaneously luteinize (Meidan et al. 1990). However, in cultured bovine granulosa cells harvested from small bovine antral follicles, the addition of low dose of FSH maintains follicle characteristics by stimulating $E_{2}$ and CYP19A1 for several days (Gutierrez et al. 1997, Silva \&
Price 2002, Sahmi et al. 2004) and appears to counteract the process of luteinization by inhibiting STAR mRNA expression (Zheng et al. 2008). Our previous study showed that TGFB1 inhibits stimulation of $E_{2}$ and $P_{4}$ synthesis in bovine granulosa cells cultured in the presence of FSH (Zheng et al. 2008). In bovine granulosa cells cultured in the absence of $\mathrm{FSH}$, the present study also shows that TGFB1 inhibits $\mathrm{P}_{4}$ secretion and the expression of $\mathrm{P}_{4}$-related enzymes STAR, CYP11A1, HSD 3B1, and GSTA, indicating an inhibition of luteinization. Similarly, inhibition of $\mathrm{P}_{4}$ secretion by TGFB1 has also been observed in bovine luteal cells (Hou et al. 2008). Conversely, in the absence of FSH, this is the first study to show that TGFB1 increases $E_{2}$ secretion and the expression of $E_{2}$-synthetic enzyme CYP19A1 and its activity in bovine granulosa cells cultured for 6 days. However, the actual amount of $E_{2}$ stimulation by TGFB1 was sixfold lower compared with $\mathrm{E}_{2}$ stimulation by $\mathrm{FSH}$, and thus the relatively low level of $E_{2}$ stimulation by TGFB1 only prevents the decline in 

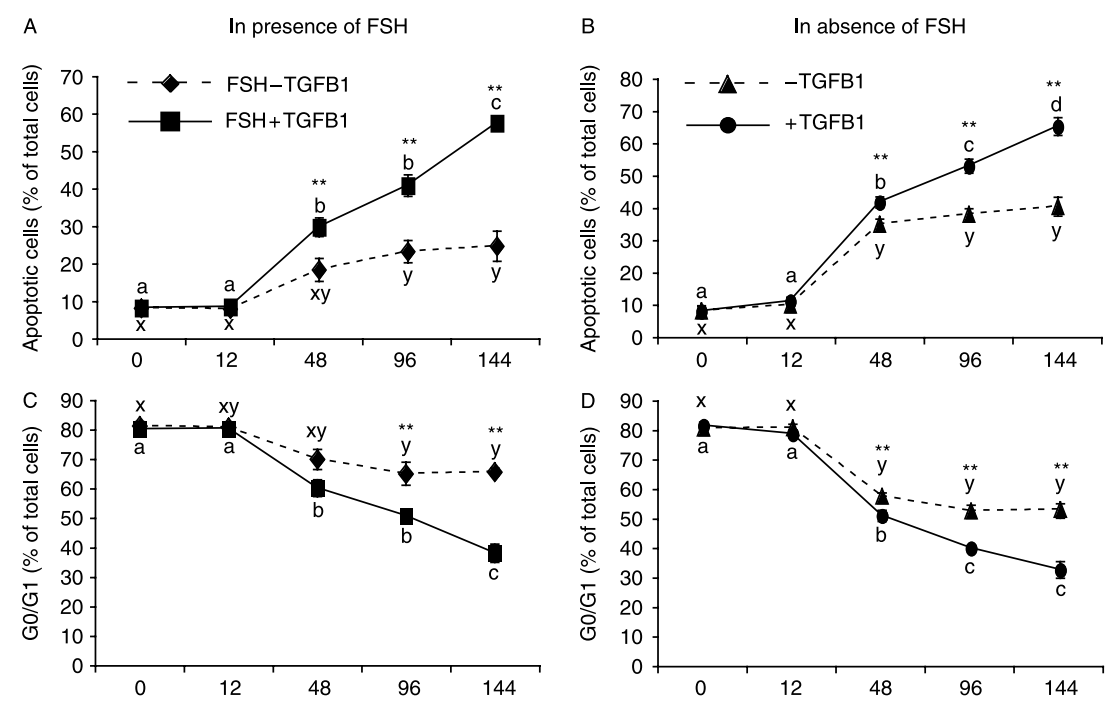

Figure 5 Effects of TGFB1 treatment on apoptosis and cell cycle phase of granulosa cells in the presence and absence of FSH. Cells were treated with TGFB1 for 6 days in the (A, C, and $\mathrm{E})$ presence or $(\mathrm{B}, \mathrm{D}$, and $\mathrm{F}$ ) absence of $\mathrm{FSH}$, stained with propidium iodide and analyzed by FACS. (A and B) The percentage of apoptotic cells relative to total cell counts, $(\mathrm{C}$ and $\mathrm{D})$ the percentage of G0/G1 cells, and (E and F) the percentage of cells in the proliferative phase of
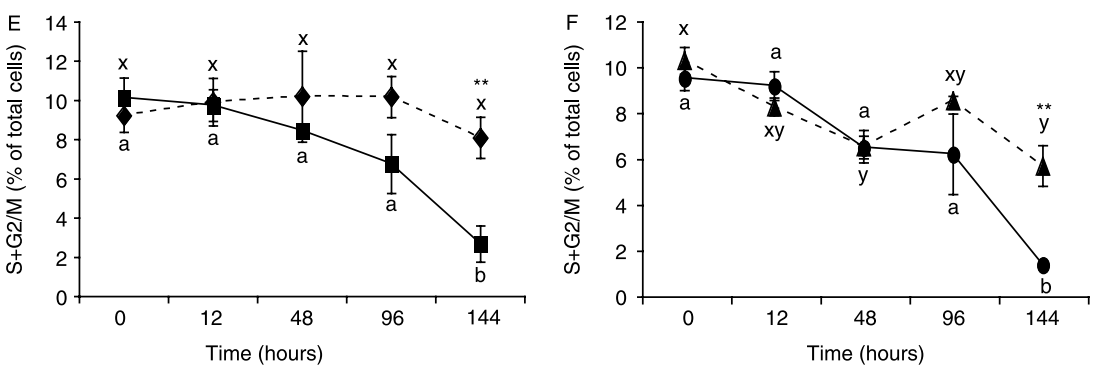
the cell cycle $(\mathrm{S}+\mathrm{G} 2 / \mathrm{M})$ are shown. Asterisk $\left({ }^{* *}\right)$ indicates significant differences $(P<0.05)$ between granulosa cells cultured with or without TGFB1 at individual time points. Different letters indicate significant differences $(P<0.05)$ between different time points in the presence of TGFB1 $(a, b, c$ and $d)$ or in the absence of TGFB1 ( $x$ and $y$ ). Data are means \pm S.E.M. of three separate culture replicates.

$\mathrm{E}_{2}$ that was observed in the absence of FSH. Furthermore, in the present study, TGFB1 stimulated expression of $H S D 17 B 1$ mRNA but did not affect expression of HSD17B7 mRNA and HSD17B-reducing activity. In our previous study, using $\mathrm{FSH}$-stimulated bovine granulosa cells, TGFB1 inhibited expression of HSD17B1 mRNA but similar to the present study, TGFB1 did not affect expression of $H S D 17 B 7$ and HSD17B-reducing activity (Zheng et al. 2008). These results confirmed that the expression of HSD17B1 mRNA does not consistently correlate with overall cellular HSD17B activity. Other candidates such as $H S D 17 B 7$ may therefore contribute to HSD17B-reducing enzyme activity in granulosa cells. In summary, the effects of TGFB1 in steroidogenesis in the absence of $\mathrm{FSH}$ indicate that this regulating factor inhibits luteinization while preserving the estrogenic phenotype of granulosa cells.

In a previous in vitro study using cultured bovine granulosa cells, $<15 \%$ of total cells were in the proliferation phase during the first day of culture with a minimal dose of FSH (Rouillier et al. 1998). At day 0, our study shows a similar percentage of cells in the proliferation phase $(10 \%)$, with most of the cells $(80 \%)$ being at the G0/G1 phase and the remainder (10\%) being in apoptosis. In the present study, spontaneous apoptosis of GCs increased with time in culture and is in agreement with a previous study using cultured bovine granulosa cells obtained from different sized follicles (Yang \& Rajamahendran 2000). In the same study, FSH was also shown to prevent apoptosis of GCs (Yang \& Rajamahendran 2000). Our results show that TGFB1 increased apoptosis in both FSH-treated and -untreated cells. TGFB1 not only sharply induced apoptosis of GCs during time in culture but also inhibited proliferation. However, the proportion of cells in the proliferative phase was very low to start with, which makes it appear likely that the previously reported decrease in protein and DNA content by TGFB1 in cultured ruminant granulosa cells (Juengel et al. 2004, Zheng et al. 2008) is due to the induction of apoptosis by TGFB1. We cannot exclude the possibility that contact inhibition may have limited cell proliferation in our culture system, and a more marked effect may have been obtained under conditions optimized for cell proliferation.

The data presented herein indicate that, in the presence or absence of FSH stimulation, TGFB1 promotes apoptosis and reduces entry into the proliferative phase of the cell cycle. Whether these effects of TGFB1 are somehow related to its effects on luteinization and steroidogenesis or whether they are wholly independent remains unclear. Recent work in bovine granulosa cells has demonstrated that granulosa cells are thought to become resistant to apoptosis through luteinization (Quirk et al. 2004). In this regard, the 

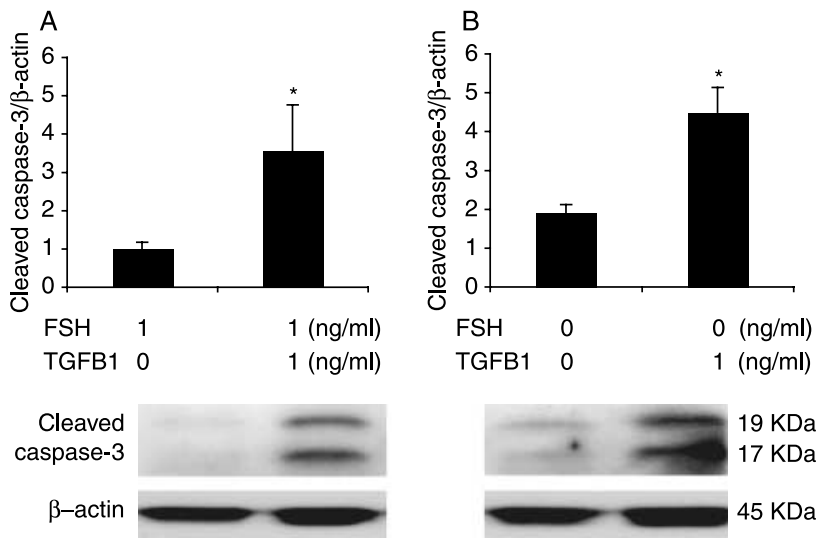

Figure 6 Western blot analysis of cleaved caspase- 3 in granulosa cells treated with TGFB1 in the presence or absence of FSH. The 17 and $19 \mathrm{kDa}$ cleaved caspase- 3 bands were normalized to the housekeeping protein $\beta$-actin. Asterisk $(*)$ indicate that cleaved caspase- 3 is significantly different from 0 dose treatment of TGFB1. Data are means \pm S.E.M. of three separate culture replicates. $(P<0.05$, one-way ANOVA, with Dunnett's test).

increased rate of apoptosis that we observed in TGFB1-treated cells may simply be a consequence of their less luteinized state. In addition, the G1/S transition phase seems to act as a critical checkpoint, at which granulosa cells may either progress through the cell cycle or undergo apoptosis, according to the relative abundance of growth and pro- or anti-apoptotic factors that may be present (Quirk et al. 2004). The presence of TGFB1 may commit a higher proportion of cells to apoptosis at the G1/S transition, resulting in a decrease in the proportion of cells at the G0/G1 phase and fewer cells in the $S$ and G2/M phases of the cycle and therefore a lesser rate of proliferation. Finally, we cannot exclude the possibility that TGFB1 also affects cell proliferation more directly by negatively regulating cell cycle progression.

Although it is often difficult to relate observations in cultured granulosa cells to follicle development in vivo, our findings may provide some insight into mechanisms of follicle selection. The bovine ovarian cycle is characterized by the recruitment of waves of small follicles, which proceed to grow until a poorly understood selection process designates a dominant follicle to continue development, while the remaining recruited follicles undergo atresia (Ireland 1987, Fortune et al. 2001). TGFB1 is expressed in the granulosa cells of bovine small antral follicles (Nilsson et al. 2003) A recent study has suggested that TGFB1 increases atresia in primary and preantral follicles (Rosairo et al. 2008). Given the pro-apoptotic properties of TGFB1 that we have observed in cultured bovine granulosa cells, it seems reasonable to speculate that its relative abundance in a given small follicle may be a determinant if it will undergo atresia (i.e. apoptosis) or achieve dominant status. In surviving follicles, the anti-luteinization properties of TGFB1 may serve to prevent the premature luteinization of follicular granulosa cells. For continued development of these surviving follicles, FSH would have to overcome TGFB1 inhibition of $\mathrm{FSH}$-induced conversion of androgens to $E_{2}$. One possible way to achieve this effect could be down-regulation of TGFB1 action. Indeed, some studies provide evidence that FSH treatment decreases TGFB1 and TGFBR1 (activin receptor-like kinase 5) mRNA expressions in cultured bovine granulosa cells (Nilsson et al. 2003, Jayawardana et al. 2006). Further studies, including experiments involving manipulation of TGFB1 activity in vivo and in vitro, will be required explore these possibilities.

In conclusion, TGFB1 negatively regulates luteinization of bovine granulosa cells, as evidenced by the inhibition of $\mathrm{P}_{4}$ secretion and $\mathrm{P}_{4}$-generating enzymes. In granulosa cells cultured in the absence of FSH, TGFB1 maintained an estrogenic phenotype. In addition, TGFB1 induced apoptosis in both FSH-stimulated and -unstimulated granulosa cells. By acting in this manner, TGFB1 may have a physiological role to control proliferation and steroidogenic differentiation of granulosa cell and may be involved in dominant follicle selection.

\section{Materials and Methods}

\section{Cell culture}

Cell culture was performed essentially as described by Gutierrez et al. (1997). Briefly, ovaries were collected at a local abattoir from adult cows irrespective of stage of the estrous cycle and transported to the laboratory at $37^{\circ} \mathrm{C}$ in PBS containing penicillin $(100 \mathrm{U} / \mathrm{ml})$, streptomycin $(100 \mu \mathrm{g} / \mathrm{ml})$, and fungizone $(1 \mu \mathrm{g} / \mathrm{ml})$. Follicles of $2-5 \mathrm{~mm}$ in diameter were dissected from the ovaries, and granulosa cells were isolated mechanically by rinsing sections of follicle walls repeatedly through a disposable pipette. The granulosa cell suspension was filtered through a 150 mesh steel sieve (Sigma) to remove oocytes.

Cells were seeded into 24-well tissue culture plates (Corning Glass Works, Corning, NY, USA) at a density of $10^{6}$ viable cells (tested by Trypan blue exclusion) in $1 \mathrm{ml}$ of $\alpha$-MEM with L-glutamine containing sodium bicarbonate $(10 \mathrm{mM})$, Hepes $(20 \mathrm{mM})$, non-essential amino acid $\operatorname{mix}(1.1 \mathrm{mM})$, penicillin $(100 \mathrm{lU} / \mathrm{ml})$ and streptomycin $(100 \mu \mathrm{g} / \mathrm{ml})$, protease-free BSA $(0.1 \%)$, sodium selenite $(4 \mathrm{ng} / \mathrm{ml})$, transferrin $(2.5 \mu \mathrm{g} / \mathrm{ml}), A_{4}$ (100 nM; all from Sigma), insulin (10 $\mathrm{ng} / \mathrm{ml}$; Invitrogen) and graded doses of recombinant active human TGFB1 (R\&D Systems, Minneapolis, MN, USA), with or without ovine FSH ( $1 \mathrm{ng} / \mathrm{ml}$; oFSH, AFP-5332B; NIDDKD, Torrance, CA, USA) starting on the first day of culture. Cultures were maintained at $37^{\circ} \mathrm{C}$ in $5 \% \mathrm{CO}_{2}$ for $2-6$ days, with $700 \mu \mathrm{l}$ medium being replaced every 2 days.

At the end of culture, medium was collected and frozen for subsequent steroid assays, and granulosa cells were collected for RNA or protein extraction. Total cell protein was extracted 
by the addition of $200 \mu \mathrm{l}$ of $1 \mathrm{M} \mathrm{NaOH}$ to each well for $2 \mathrm{~h}$ at room temperature, followed by neutralization with $200 \mu \mathrm{l}$ of $1 \mathrm{M} \mathrm{HCl}$. Protein concentrations were measured using the BioRad micro-assay (Bio-Rad). All experiments were performed with at least three independent cell cultures.

\section{Steroid assays}

Culture medium samples were assayed for $E_{2}$ as previously reported (Bélanger et al. 1990) but without C-18 column extraction. Cross-reaction of $A_{4}$ and $E_{1}$ with the $E_{2}$ assay was $<0.1 \%$ (Bélanger et al. 1980). $P_{4}$ was measured in duplicate as described (Lafrance \& Goff 1985). Intra- and inter-assay coefficients of variation were $<15 \%$ for both assays. The sensitivity of the $E_{2}$, and $P_{4}$ assays were 5 and $18 \mathrm{pg}$ per tube respectively. The steroid hormone concentrations were corrected for cell number by normalization to total cell protein.

\section{RT-PCR}

Total RNA was extracted using TRIzol reagent (Invitrogen) according to the manufacturer's instructions and treated with DNAse (Qiagen). RT was performed on $1 \mu \mathrm{g}$ total RNA with Omniscript enzyme (Qiagen). Gene expression was measured by semi-quantitative PCR. The primers used were those described previously (Zheng et al. 2008). PCR was performed under the following conditions: 1) initial denaturation at $94{ }^{\circ} \mathrm{C}$ for $3 \mathrm{~min}$; 2) amplification cycles of denaturation at $94{ }^{\circ} \mathrm{C}$ for $45 \mathrm{~s}$, annealing for $45 \mathrm{~s}$ at $60^{\circ} \mathrm{C}(C Y P 11 A 1$ and $H S D 3 B 1)$ or $64{ }^{\circ} \mathrm{C}\left(H S D 17 B 1, H S D 17 B 7\right.$, and GSTA), or for $30 \mathrm{~s}$ at $62^{\circ} \mathrm{C}$ (STAR, 1B15, and CYP19A1); 3) elongation at $72{ }^{\circ} \mathrm{C}$ for $1 \mathrm{~min}$; 4) final elongation at $72{ }^{\circ} \mathrm{C}$ for $5 \mathrm{~min}$. Optimal cycle number for amplification during the exponential phase was determined for each gene. The reactions were performed for 27 cycles for 1b15, 31 cycles for STAR, 35 cycles for CYP11A1, 34 cycles for HSD3B1, 25 cycles for GSTA, 38 cycles for CYP19A1, 36 cycles for $H S D 17 B 1$ and $H S D 17 B 7$. The PCR products were separated on $2 \%$ agarose gels containing $0.001 \%$ ethidium bromide and visualized under u.v. light. Quantification of band intensity was performed with NIH Image J software (developed at the US National Institutes of Health and available on the Internet at http://rsb.info.nih.gov/nih-image/). Specific gene mRNA abundance was normalized to 1 b15 mRNA abundance.

\section{Enzyme activity assays}

Incubation of tritiated steroid hormone precursors was conducted at the end of day 6 of culture to measure specific enzyme activities. On day 6 , all the medium of each well was removed and replaced with fresh medium without $\mathrm{A}_{4}$ but containing $6-11 \mathrm{nM}\left(1.6 \times 10^{6} \mathrm{DPM} / \mathrm{ml}\right.$ medium $)$ of either $\left[{ }^{3} \mathrm{H}\right]-\mathrm{E}_{1},\left[{ }^{3} \mathrm{H}\right]-\mathrm{A}_{4}$, or $\left[{ }^{3} \mathrm{H}\right]$-testosterone $\left(\left[{ }^{3} \mathrm{H}\right]-\mathrm{T}\right)$ and $0,0.5$ or $1 \mathrm{ng} / \mathrm{ml}$ of TGFB1. Cells were incubated for 1.5 to $48 \mathrm{~h}$ at $37^{\circ} \mathrm{C}$. At the end of the incubation, medium was recovered and frozen at $-20{ }^{\circ} \mathrm{C}$ until analysis of steroid metabolism by thin layer chromatography (TLC) as previously described (Godin et al. 1999). Briefly, steroids were extracted from the medium using diethyl ether and resolved on DC-Alufolien neutral (Type E) paper plates (Whatman, Maidstone, Kent, England, UK) in toluene:acetone (4:1). Each TLC plate contained $\left[{ }^{3} \mathrm{H}\right]-\mathrm{E}_{1}$, $\left[{ }^{3} \mathrm{H}\right]-\mathrm{E}_{2},\left[{ }^{3} \mathrm{H}\right]-\mathrm{A}_{4}$, and $\left[{ }^{3} \mathrm{H}\right]-\mathrm{T}$ as standards. A culture medium control was performed by incubating tracer in culture medium without cells, and was used to obtain background radioactivity that was subtracted from product counts. After migration of samples, TLC plates were exposed to phosphor screens designed for tritium detection, and tritiated steroid metabolites were localized with a Storm 840 phosphorimager (Molecular Dynamics, Sunnyvale, CA, USA). The rate of production of specific steroid metabolites was quantified by scraping the corresponding sample and background spots from the TLC plate and counting radioactivity using PCS scintillation fluid (Amersham).

Activity assays were validated in bovine granulosa cells cultured without FSH by determining the conditions required to maintain excess substrate. In preliminary time course experiments without $\mathrm{FSH}$ treatment, $1.6 \times 10^{6} \mathrm{DPM}$ of $\left[{ }^{3} \mathrm{H}\right]-\mathrm{A}_{4}$ and $\left[{ }^{3} \mathrm{H}\right]-\mathrm{T}(6-11 \mathrm{nM})$ were incubated with granulosa cells for 12,24 , and $48 \mathrm{~h}$. In 12 and $24 \mathrm{~h}$ incubations, the conversion of $\left[{ }^{3} \mathrm{H}\right]-\mathrm{A}_{4}$ and $\left[{ }^{3} \mathrm{H}\right]-\mathrm{T}$ precursors to $\left[{ }^{3} \mathrm{H}\right]-\mathrm{E}_{2}$ was too low to be detected. After 48-h incubation, the amount of conversion of $\left[{ }^{3} \mathrm{H}\right]-\mathrm{A}_{4}$ and $\left[{ }^{3} \mathrm{H}\right]-\mathrm{T}$ precursors to $\left[{ }^{3} \mathrm{H}\right]-\mathrm{E}_{2}$ was 13.8 and $5.7 \%$ respectively, and thus an incubation time of $48 \mathrm{~h}$ was selected. For HSD17B-reducing activity, unlabeled $\mathrm{E}_{1}$ $\left(10^{-6} \mathrm{M}\right)$ was added to the $8.8 \mathrm{pmol} / \mathrm{ml}$ of $\left[{ }^{3} \mathrm{H}\right]-\mathrm{E}_{1}$, and incubation time was $1.5 \mathrm{~h}$. This resulted in $13.7 \%$ conversion of $\left[{ }^{3} \mathrm{H}\right]-\mathrm{E}_{1}$ to $\left[{ }^{3} \mathrm{H}\right]-\mathrm{E}_{2}$ and therefore $10^{-6} \mathrm{M}$ unlabeled $\mathrm{E}_{1}$ was added to all $\left[{ }^{3} \mathrm{H}\right]-\mathrm{E}_{1}$ incubations.

\section{Cell cycle and apoptosis analysis by flow cytometry}

Flow cytometry using a fluorescence-activated cell sorter (FACS) has been used to determine the proportion of granulosa cells in the different phases of the cycle, and is a recognized method to quantify the rate of apoptosis (Nicoletti et al. 1991, Rouillier et al. 1998). After removing the media, granulosa cells were detached by rinsing with PBS and were then centrifuged at $500 \mathrm{~g}$ for $5 \mathrm{~min}$ at $4{ }^{\circ} \mathrm{C}$ and washed a second time in PBS. Cells were fixed by drop-wise addition of $1 \mathrm{ml}$ ice-cold $70 \%$ ethanol while vortexing. Ethanol-fixed cells were stored at $4{ }^{\circ} \mathrm{C}$ for at least $24 \mathrm{~h}$ before PI staining. Granulosa cells were centrifuged $500 \mathrm{~g}$ for $5 \mathrm{~min}$ at $4{ }^{\circ} \mathrm{C}$, ethanol removed, and then treated with $0.5 \mathrm{ml}$ of $\mathrm{Pl}$ staining solution $(1 \mathrm{mg} / \mathrm{ml} \mathrm{PI}, 0.1 \%$ TritonX-100 and $0.2 \mathrm{mg} / \mathrm{ml}$ RNase A in $1 \times$ PBS). Stained cells were held at room temperature in the dark for at least $1 \mathrm{~h}$ before FACS analysis. Immediately before analysis, cells were passed through a $70 \mu \mathrm{m}$ nylon mesh sieve to obtain a single-cell suspension and to remove aggregated cells. Flow cytometry analysis was performed with a BD Bioscience FACSVantage SE. Apoptotic cells or their isolated nuclei show a low DNA stainability resulting in a distinct, quantifiable region below the G0/G1 peak. The proportion of apoptotic cells and the proportion of cells in G0/G1, S, and G2/M phases of the cell cycle were calculated using Cell Quest Pro software (BD Bioscience, Oakville, ON, Canada). 


\section{Western blotting}

Granulosa cells were lysed using Mammalian Protein Extraction Reagent (M-PER, Thermo Scientific, Rockford, IL, USA) and $25 \mu \mathrm{g}$ protein samples were separated electrophoretically on a $18 \%$ SDS-polyacrylamide gel, transferred to a PVDF membrane, blocked in 5\% non-fat dried milk in Tris-buffered saline with Tween (TBST), and incubated overnight $\left(4{ }^{\circ} \mathrm{C}\right)$ with the primary antibody, anti-cleaved caspase-3 (Asp175, Cell Signaling Technology, Danvers, MA, USA). After washing with TBST thrice, secondary antibody was added and incubated $1 \mathrm{~h}$ at room temperature and protein bands were visualized using ECL Plus (Amersham). The membranes were then stripped and re-probed with a mouse anti- $\beta$-actin antibody (Santa Cruz Biotechnology, Santa Cruz, CA, USA). The molecular size of immunoreactive bands was determined by co-migration of a ladder of low-range rainbow molecular weight markers (Amersham) applied to a lane in each gel. Protein expression was calculated as the ratio of each specific band to corresponding $\beta$-actin signals. Experiments were repeated thrice.

\section{Statistical analysis}

All statistical analyses were performed using JMP software (SAS Institute, Cary, NC, USA). The data are presented as means \pm S.E.M. of duplicate to triplicate measurements in at least three separate cultures. Data were transformed to logarithms if they were not normally distributed as verified using the Shapiro-Wilk test. One-way ANOVA was used to test the main effect of time and TGFB1 on $\mathrm{E}_{2}$ secretion, $\mathrm{P}_{4}$ secretion, steroidogenic enzyme activities, and protein expression of cleaved caspase-3. Differences between treatment dose of TGFB1 with the 0 dose control; or between 4 and 6 day cultures and the 2-day culture group were identified with Dunnett's test. Two sets of analyses were performed in flow cytometry experiments. First, the effect of time in culture on $\%$ apoptotic cells, \% G0/G1, and \% S+G2/M were analyzed from 0 to $144 \mathrm{~h}$ in the presence or absence of FSH and TGFB1. Differences at each time point were identified with Tukey HSD's all pairs comparison. Second, one-way ANOVA was used to test the effect of TGFB1 on the measured parameters of each time point. Differences between treatment doses of TGFB1 with the 0 dose control were identified with Dunnett's test. A probability of $P<0.05$ was considered to be statistically significant.

\section{Declaration of interest}

The authors declare that there is no conflict of interest that could be perceived as prejudicing the impartiality of the research reported.

\section{Funding}

This research was funded by a Natural Sciences and Engineering Research Council (NSERC) of Canada.

\section{Acknowledgements}

We thank Dr Yves Tremblay of CHUL, Université Laval, Québec City, for assistance in TLC and Dr Patrick Vincent and Ms Marie-Noëlle Laguë for technical assistance.

\section{References}

Adashi EY, Resnick CE, Hernandez ER, May JV, Purchio AF \& Twardzik DR 1989 Ovarian transforming growth factor-beta (TGF beta): cellular site(s), and mechanism(s) of action. Molecular and Cellular Endocrinology 61 247-256.

Bao B \& Garverick HA 1998 Expression of steroidogenic enzyme and gonadotropin receptor genes in bovine follicles during ovarian follicular waves: a review. Journal of Animal Science 76 1903-1921.

Bélanger A, Caron S \& Picard V 1980 Simultaneous radioimmunoassay of progestins, androgens and estrogens in rat testis. Journal of Steroid Biochemistry 13 185-190.

Bélanger A, Couture J, Caron S \& Roy R 1990 Determination of nonconjugated and conjugated steroid levels in plasma and prostate after separation on C-18 columns. Annals of the New York Academy of Sciences 595 251-259.

Boone DL \& Tsang BK 1998 Caspase-3 in the rat ovary: localization and possible role in follicular atresia and luteal regression. Biology of Reproduction 58 1533-1539.

Chang WY, Shidaifat F, Uzumcu M \& Lin YC 1996 Effects of transforming growth factor- $\beta 1$ and activin-A on in vitro porcine granulosa cell steroidogenesis. Theriogenology 45 1463-1472.

Dodson WC \& Schomberg DW 1987 The effect of transforming growth factor-beta on follicle-stimulating hormone-induced differentiation of cultured rat granulosa cells. Endocrinology 120 512-516.

Dorrington JH, Bendell JJ \& Khan SA 1993 Interactions between FSH, estradiol-17 beta and transforming growth factor-beta regulate growth and differentiation in the rat gonad. Journal of Steroid Biochemistry and Molecular Biology 44 441-447.

Drummond AE 2006 The role of steroids in follicular growth. Reproductive Biology and Endocrinology 416.

Ford JJ \& Howard HJ 1997 Activin inhibition of estradiol and progesterone production in porcine granulosa cells. Journal of Animal Science $\mathbf{7 5}$ 761-766.

Fortune JE, Rivera GM, Evans AC \& Turzillo AM 2001 Differentiation of dominant versus subordinate follicles in cattle. Biology of Reproduction 65 648-654.

Gangrade BK \& May JV 1990 The production of transforming growth factorbeta in the porcine ovary and its secretion in vitro. Endocrinology 127 2372-2380.

Godin C, Provost PR, Poirier D, Blomquist CH \& Tremblay Y 1999 Separation by thin-layer chromatography of the most common androgen-derived C19 steroids formed by mammalian cells. Steroids 64 767-769.

Gutierrez CG, Campbell BK \& Webb R 1997 Development of a longterm bovine granulosa cell culture system: induction and maintenance of estradiol production, response to follicle-stimulating hormone, and morphological characteristics. Biology of Reproduction $\mathbf{5 6}$ 608-616.

Herrmann M, Scholmerich J \& Straub RH 2002 Influence of cytokines and growth factors on distinct steroidogenic enzymes in vitro: a short tabular data collection. Annals of the New York Academy of Sciences 966 166-186.

Hou X, Arvisais EW, Jiang C, Chen DB, Roy SK, Pate JL, Hansen TR, Rueda BR \& Davis JS 2008 Prostaglandin F2 $\alpha$ stimulates the expression and secretion of transforming growth factor B1 via induction of the early growth response 1 gene (EGR1) in the bovine corpus luteum. Molecular Endocrinology 22 403-414.

Hu CL, Cowan RG, Harman RM \& Quirk SM 2004 Cell cycle progression and activation of Akt kinase are required for insulin-like growth factor I-mediated suppression of apoptosis in granulosa cells. Molecular Endocrinology 18 326-338. 
Ingman WV, Robker RL, Woittiez K \& Robertson SA 2006 Null mutation in transforming growth factor $\beta 1$ disrupts ovarian function and causes oocyte incompetence and early embryo arrest. Endocrinology 147 835-845.

Ireland JJ 1987 Control of follicular growth and development. Journal of Reproduction and Fertility 34 39-54.

Jayawardana BC, Shimizu T, Nishimoto H, Kaneko E, Tetsuka M \& Miyamoto A 2006 Hormonal regulation of expression of growth differentiation factor-9 receptor type I and II genes in the bovine ovarian follicle. Reproduction 131 545-553.

Johnson AL \& Bridgham JT 2002 Caspase-mediated apoptosis in the vertebrate ovary. Reproduction 124 19-27.

Juengel JL \& McNatty KP 2005 The role of proteins of the transforming growth factor- $\beta$ superfamily in the intraovarian regulation of follicular development. Human Reproduction Update 11 143-160.

Juengel JL, Bibby AH, Reader KL, Lun S, Quirke LD, Haydon LJ \& McNatty KP 2004 The role of transforming growth factor-beta (TGF-beta) during ovarian follicular development in sheep. Reproductive Biology and Endocrinology 278.

Kulkarni AB, Huh CG, Becker D, Geiser A, Lyght M, Flanders KC, Roberts AB, Sporn MB, Ward JM \& Karlsson S 1993 Transforming growth factor $\beta 1$ null mutation in mice causes excessive inflammatory response and early death. PNAS $90770-774$.

Lafrance M \& Goff AK 1985 Effect of pregnancy on oxytocin-induced release of prostaglandin F2 $\alpha$ in heifers. Biology of Reproduction 33 1113-1119.

Matikainen T, Perez GI, Zheng TS, Kluzak TR, Rueda BR, Flavell RA \& Tilly JL 2001 Caspase-3 gene knockout defines cell lineage specificity for programmed cell death signaling in the ovary. Endocrinology 142 2468-2480.

Meidan R, Girsh E, Blum O \& Aberdam E 1990 In vitro differentiation of bovine theca and granulosa cells into small and large luteal-like cells: morphological and functional characteristics. Biology of Reproduction 43 913-921.

Mindnich R, Moller G \& Adamski J 2004 The role of 17 -hydroxysteroid dehydrogenases. Molecular and Cellular Endocrinology 218 7-20.

Nicholas B, Alberio R, Fouladi-Nashta AA \& Webb R 2005 Relationship between low-molecular-weight insulin-like growth factor-binding proteins, caspase-3 activity, and oocyte quality. Biology of Reproduction 72 796-804.

Nicoletti I, Migliorati G, Pagliacci MC, Grignani F \& Riccardi C 1991 A rapid and simple method for measuring thymocyte apoptosis by propidium iodide staining and flow cytometry. Journal of Immunological Methods $139271-279$.

Nilsson EE, Doraiswamy V \& Skinner MK 2003 Transforming growth factor$\beta$ isoform expression during bovine ovarian antral follicle development. Molecular Reproduction and Development 66 237-246.

Ouellette Y, Price CA \& Carriere PD 2005 Follicular fluid concentration of transforming growth factor- $\beta 1$ is negatively correlated with estradiol and follicle size at the early stage of development of the first-wave cohort of bovine ovarian follicles. Domestic Animal Endocrinology 29 623-633.

Quirk SM, Cowan RG, Harman RM, Hu CL \& Porter DA 2004 Ovarian follicular growth and atresia: the relationship between cell proliferation and survival. Journal of Animal Science 82 E40-E52.

Rabahi F, Brule S, Sirois J, Beckers JF, Silversides DW \& Lussier JG 1999 High expression of bovine alpha glutathione S-transferase (GSTA1,
GSTA2) subunits is mainly associated with steroidogenically active cells and regulated by gonadotropins in bovine ovarian follicles. Endocrinology 140 3507-3517.

Raffalli-Mathieu F, Persson D \& Mannervik B 2007 Differences between bovine and human steroid double-bond isomerase activities of alphaclass glutathione transferases selectively expressed in steroidogenic tissues. Biochimica et Biophysica Acta 1770 130-136.

Rosairo D, Kuyznierewicz I, Findlay J \& Drummond A 2008 Transforming growth factor- $\beta$ : its role in ovarian follicle development. Reproduction 136 811-822.

Rouillier P, Matton P, Dufour M, Sirard MA \& Guilbault LA 1998 Steroid production, cell proliferation, and apoptosis in cultured bovine antral and mural granulosa cells: development of an in vitro model to study estradiol production. Molecular Reproduction and Development $\mathbf{5 0}$ 170-177.

Sahmi M, Nicola ES, Silva JM \& Price CA 2004 Expression of $17 \beta$ - and $3 \beta$ hydroxysteroid dehydrogenases and steroidogenic acute regulatory protein in non-luteinizing bovine granulosa cells in vitro. Molecular and Cellular Endocrinology 223 43-54.

Shull MM, Ormsby I, Kier AB, Pawlowski S, Diebold RJ, Yin M, Allen R, Sidman C, Proetzel G, Calvin D et al. 1992 Targeted disruption of the mouse transforming growth factor- $\beta 1$ gene results in multifocal inflammatory disease. Nature 359 693-699.

Silva MJ \& Price CA 2002 Insulin IGF-I are necessary for FSH-induced cytochrome P450 aromatase but not cytochrome P450 side-chain cleavage gene expression in oestrogenic bovine granulosa cells in vitro. Journal of Endocrinology 174 499-507.

Skinner MK, Keski-Oja J, Osteen KG \& Moses HL 1987 Ovarian thecal cells produce transforming growth factor- $\beta$ which can regulate granulosa cell growth. Endocrinology 121 786-792.

Tilly JL, Kowalski KI, Johnson AL \& Hsueh AJ 1991 Involvement of apoptosis in ovarian follicular atresia and postovulatory regression. Endocrinology 129 2799-2801.

Wandji SA, Eppig JJ \& Fortune JE 1996 FSH and growth factors affect the growth and endocrine function in vitro of granulosa cells of bovine preantral follicles. Theriogenology 45 817-832.

Yang MY \& Rajamahendran R 2000 Morphological and biochemical identification of apoptosis in small, medium, and large bovine follicles and the effects of follicle-stimulating hormone and insulin-like growth factor-I on spontaneous apoptosis in cultured bovine granulosa cells. Biology of Reproduction 62 1209-1217.

Zheng X, Price CA, Tremblay Y, Lussier JG \& Carriere PD 2008 Role of transforming growth factor- $\beta 1$ in gene expression and activity of estradiol and progesterone-generating enzymes in FSH-stimulated bovine granulosa cells. Reproduction 136 447-457.

Received 25 August 2008

First decision 8 October 2008

Revised manuscript received 29 January 2009

Accepted 23 March 2009 